\title{
MICROHABITAT PREFERENCES OF PHAEOPHYTA ON SHORE PLATFORM OF DWARKA, GUJARAT COAST, INDIA
}

\author{
Dimpal SANGHVI *, Nandini RAY CHAUDHURY ** and Bhanukumar JAIN **
}

* M. G. Science Institute, Department of Botany, Navarangpura, Ahmedabad, Gujarat, India, IN-300009, dimpalsanghvi@gmail.com

** Indian Space Research Organisation, Space Applications Centre, Environment and Hydrology Division, Biological and Planetary Sciences and Applications Group, Earth, Ocean, Atmosphere and Planetary Sciences Area, Jodhpur Tekra, Ambavadi Vistar, Ahmedabad, Gujarat, India, IN-38001, nandinirc@sac.isro.gov.in, bkjain_mgsc@yahoo.com.

DOI: 10.1515/trser-2015-0060

KEYWORDS: Marine algae, Phaeophyta, microhabitats, shore platform, Dwarka.

\section{ABSTRACT}

This paper reports microhabitat preferences of Phaeophyta from the shore platform, Dwarka, Gujarat coast, India. Macroalgae distribution was tagged with shore platform's zonal morphology. Macroalgae (Phaeophyta) were surveyed based on systematic random sampling for two years (April, 2013 to March, 2015). Total 21 species of Phaeophyta were identified through intensive fieldwork/in situ survey based on Line Intercept Transect and Quadrate based methods. Five groups of Phaeophyta were identified as per their zonal preference on the shore platform. On family level, most of the Sargassaceae showed a ubiquitous distribution on the shore platform while Dictyotaceae showed preference towards the subtidal and intertidal mixed zone of the shore platform.

RESUMEN: Preferencias de microhabitat de algas pardas en la plataforma costera de Dwarka, costa de Gujarat, India.

En este artículo se reportan las preferencias de microhábitat de las Phaeophytas de la plataforma continental de Dwarka, en la costa de Gujarat, India. Se mapeó la distribución de las macrofítas mediante la morfología zonal de la plataforma costera. Las macroalgas (Phaoeophyta) se colectaron mediante un muestreo sistemático al azar durante dos años (abril de 2013 a marzo de 2015). Tras un muestreo intensivo en campo, basado en trayectos lineales y cuadrantes, se identificó un total de 21 especies de algas pardas. Se identificaron cinco grupos con preferencia a la plataforma costera. A nivel familia, Sargasseaceae mostró ubiquidad en la plataforma, mientras que en Dictyotaceae se evidenció preferencia a la zona mareal e intermareal.

REZUMAT: Preferințe de microhabitat ale Phaeophyta pe platforma costieră Dwarka, Coasta Gujarat, India.

Prezentul articol indică preferințele de microhabitat ale Phaeophyta de pe platforma costieră Dwarka, în largul provinciei Gujarat, India. Distribuția macroalgelor a fost identificată în funcție de morfologia zonală a platformei costiere. Macroalgele (Phaeophyta) au fost studiate pe baza unei eșantionări aleatorii timp de doi ani (aprilie 2013 - martie 2015). În total 21 specii au fost identificate prin campanii intensive de teren/studiere in situ pe baza metodei de transect cu intersectare de linii și a metodei pătratelor. Au fost identificate cinci grupuri de Phaeophyta în funcție de preferințele zonale de pe platforma continentală. La nivel de familii, majoritatea Sargassaceelor au prezentat o distribuție ubicvistă pe platforma costieră, în timp ce Dictyoceele au prezentat preferințe pentru zona de amestec subtidală și intertidală a platformei costiere. 


\section{INTRODUCTION}

Marine macroalgae are commonally known as seaweeds in the world. They grow in the intertidal and subtidal zones, in the estuaries and backwaters on solid substrates such as rocks, corals, pebbles, shells and even on plant materials (Sanghvi et al., 2014). Conventionally seaweeds include any large marine benthic algae that are multicellular, macrothallic and thus differentiated from most algae that are of microscopic size (Subba Rao and Mantri, 2006). In the marine ecosystem, marine algae are ecologically important as they provide nutrition and accommodation to other living organisms on an ecological base. These plants form an important renewable resource in the marine environment. They have been part of human civilization from ancient times (Subba Rao and Mantri, 2006). Seaweeds are one of the most important marine living resources for food, feed and raw materials for medicines, cosmetics and industries.

Shore platform is stable compared to other soft substratum environments like beach. It supports many different kinds of plants and animals, some underwater, while other parts are dry stable substratum to the marine algae. There can be distinct patterns of spatial distribution of different species of macroalgae on the shore platform even at minute scale.

Three major groups of seaweeds Chlorophyta, Phaeophyta and Rhodophyta are recognized according to their pigments that absorb light of particular wavelength and give them their characteristic colour of green, brown and red (Thahira, 2011). Out of these three, the brown algae (Phaeophyta) are multi-cellular and are found in a variety of physical forms including crusts and filaments. It contains green pigments chlorophyll and gold and brown pigments: fucoxanthin. Phaeophyta is the most complex algae. Brown algae are almost exclusively marine. They exit either in a uniaxial branched filaments or in a large elaborately parencymatous thalloid organization; usually of the defined form. In majority generally a holdfast, a long or short stipe and an expanded blade work as a photosynthetic and a reproductive structure are present. They are found all over the world.

Phaeophyta play the ecological roles of a decomposer, producer and a food source for aquatic life, very important for the aquatic biodiversity form important habitats for marine life. For instance macrocystis, a kelp of the order Laminariales may reach $60 \mathrm{~m}$ in length and form prominent underwater forests. Sargassum sp. creates unique habitats in the tropical waters of the Sargasso Sea. Phaeophyta like Sargassum sp. and other rockweed such as Fucus sp. float in a thick tangled mass through the Sargasso Sea, which supports a variety of marine organisms. Phaeophyta are commonly used as food thickeners, stabilizers and fillers. Phaeophyta hold high carbon dioxide levels used in photosynthesis. Kelp, which is the general name for large Phaeophyta constitutes an important source of iodine, mineral salts, bromine and potash. Some are used as fertilizers because of their high content of nitrogen, potassium and other minerals. The fertilizers contain all the micronutrients required for plants. From the cell wall of Phaeophyta, a gel forming substance is obtained. Algin is used to manufacture chemicals. Alginates are used in production of food and drugs in industries such as food, paper, pharmaceutical, textile and welding.

Phaeophyta species have seasonal nature, species level preference to habitat. This study was carried out to certain species specific microhabitat preferences of the Phaeophyta group on the shore platform of Dwarka, Gujarat coast, India. Following are the objectives of the present work: to study spatial variation of Phaeophyta; to study the microhabitat preference of Phaeophyta in Dwarka. 


\section{MATERIALS AND METHODS}

Study Area. For seaweeds' growth, geographical, geological, topographical and physical nature of the shore is important. Rocky coasts have vertical zonation (Woodward, 2003). Shore platform provides stable coastal environment as compared to soft sediment coasts like beaches and spits. It represents a case environment where majority of macroalgae species grow with a firm substratum attachment. India has 7,516.6 km of coastline including the island territories with diverse coastal habitats and rich biota (Singh et al., 2012). Out of this, the coastline of Gujarat state is $1,600 \mathrm{~km}$. It represents the north-western most part of peninsular India. This coastline occurs within the geographical limits of $20^{\circ} 00^{\prime}$ to $24^{\circ} 45^{\prime} \mathrm{N}$ and $68^{\circ} 00^{\prime}$ to $78^{\circ} 30^{\prime}$ E. Gujarat coast extends in the form of four major coastal ecological components from North to South: I) Kori creek; II) Gulf of Kachchh; III) Saurashtra coast from Okha to Porbandar, and IV) Gulf of Khambhat. Gujarat coastline is reportedly rich with diversity of seaweeds (Chakraborty and Bhattacharya, 2012). The substratum of Gujarat coast is rocky in many parts, which provides suitable environment for macroalgae growth (Chakraborty and Bhattacharya, 2012). The Saurashtra coast, which runs for an approximate length of $985 \mathrm{~km}$, is characterized by rocky, sandy and muddy intertidal zones, harbouring rich and varied flora and fauna (Gohil and Kundu, 2012). The present study was carried out on the shore platform of Dwarka, located on the Saurashtra coast, Gujarat, India $\left(22^{\circ} 14^{\prime} 22^{\prime \prime}-22^{\circ} 14^{\prime} 38^{\prime \prime} \mathrm{N}\right.$ and $\left.68^{\circ} 57^{\prime} 15^{\prime \prime}-68^{\circ} 57^{\prime} 25^{\prime \prime} \mathrm{E}\right)$ (Figs. 1A and 1B). Total length of the study area is $572.28 \mathrm{~m}$, maximum width of the shore platform sampled is $143.8 \mathrm{~m}$ and it covers a surface area of $82,293.86 \mathrm{~m}^{2}$. Previous surveys of marine algal resources along the Gujarat coast, performed at the intertidal zones, have revealed great diversity of marine algae in this region (Dhargalkar and Deshmukhe, 1996). In this area three groups of seaweeds: Chlorophyta, Phaeophyta and Rhodophyta were found. Sanghvi et al. (2014) has reported 16 Chlorophyta, 11 Phaeophyta and nine Rhodophyta species of algae under each group. For the present study, Phaeophyta group was selected.

Field Data Collection. The study area was divided into three sections in NorthSouth directions: I) Northern; II) Central; III) Southern sections for systematic field sampling. Field sampling of seaweeds was done from April, 2013 to March, 2015 considering annual cycles of each year. Field surveys/samplings were performed during low tides. For qualitative and quantitative assessment, GPS (Spheroid and Datum: WGS 84) tagged Line Intercept Transect (LIT) were carried out. The length of the transect lines depended on the tidal exposure of the shore platform during the surveys. Maximum depth of the subtidal zone sampled for seaweeds in the present study is $0.5 \mathrm{~m}$. For quantitative assessment of the seaweeds in the given area, line transect was laid perpendicular to the coast in a seaward direction with the help of a long rope of $50 \mathrm{~m}$ (Dhargalkar and Kavlekar, 2004). A sampling point along the rope is marked depending on the gradient and exposure of intertidal and subtidal areas. In Saurashtra coast, the tidal amplitude is quite high as compared to other parts of the Indian coast and the west coast in particular. Growth of seaweeds in intertidal and shallow subtidal regions can be easily observed in this area as the spring tides expose the intertidal area up to a maximum length of one km (Jha et al., 2009). Each of the three sections on the shore platform was represented by one transect line: thus resulting 33 transect lines over two years' sampling. Quadrates of one $\mathrm{m}^{2}$ were positioned on the transect lines wherever the algae growth, density and diversity were high. Total 258 quadrates were performed on the thirty three transect lines. GPS tagged photos of quadrates were taken for further analysis. Seaweed species present within the quadrates were sampled. 

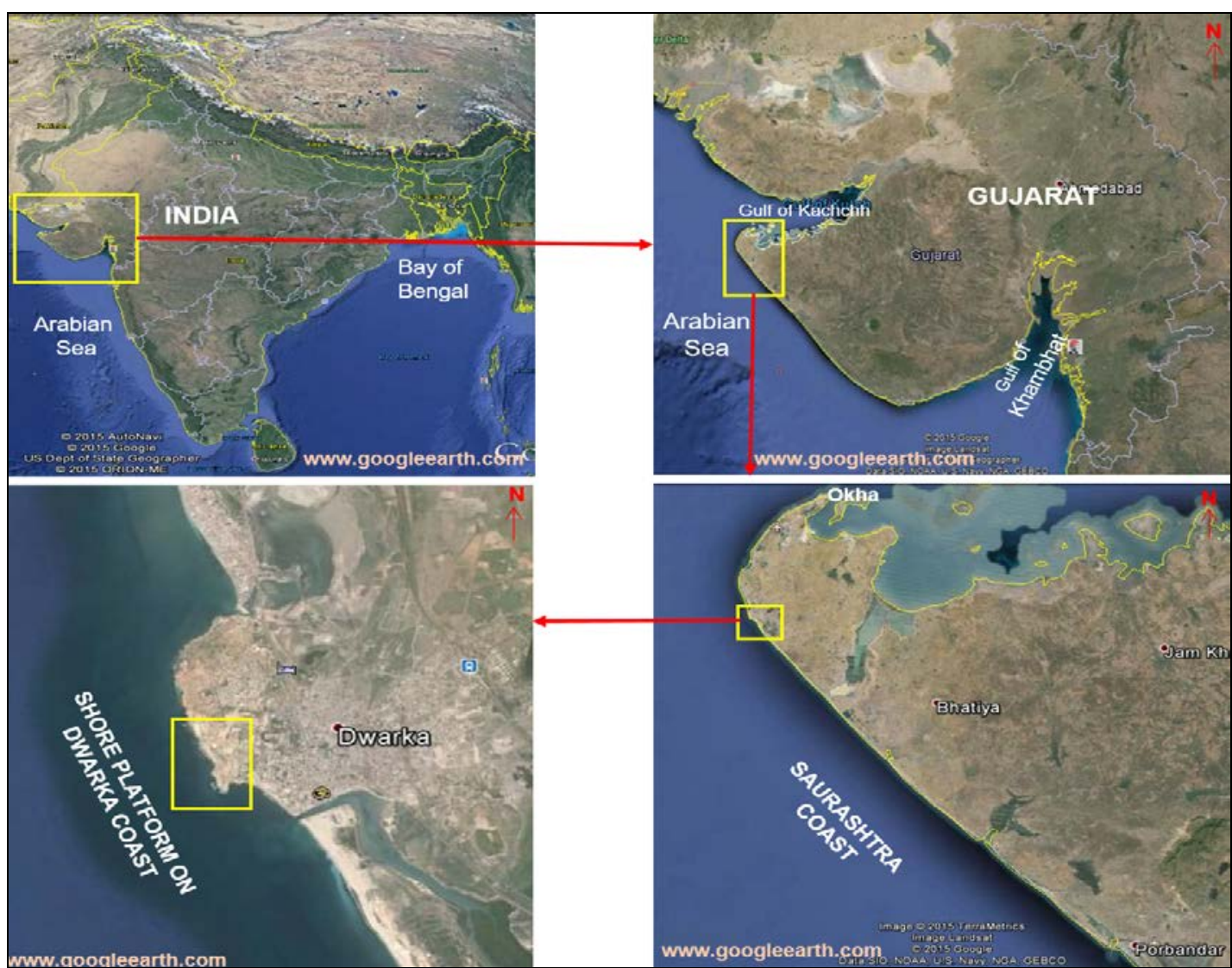

Figure 1A: Location of Shore Platform on Dwarka Coast, Gujarat, India.

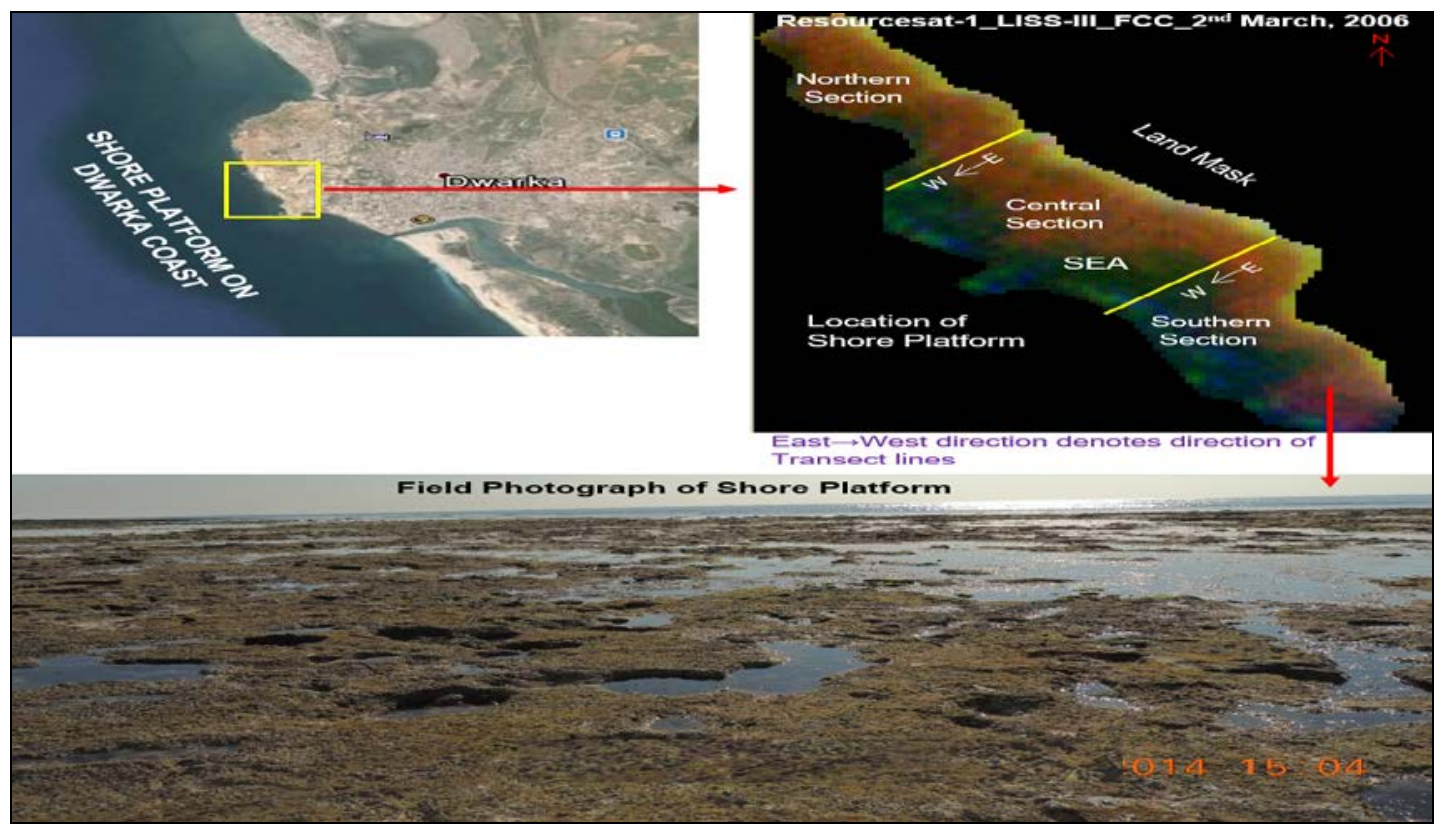

Figure 1B: Study Site: Shore Platform of Dwarka. 


\section{Field Data Analysis}

Seaweed samples were collected from field and taken to laboratory for preparation of herbarium sheets and specimen identification. Morphological criteria and reproductive structure were analyzed for taxa identification. A cladogram was prepared for identifying algae species in order to generate classification statistics of Phaeophyta i.e. number of genera and species pertaining to different classes as shown in figure 2.

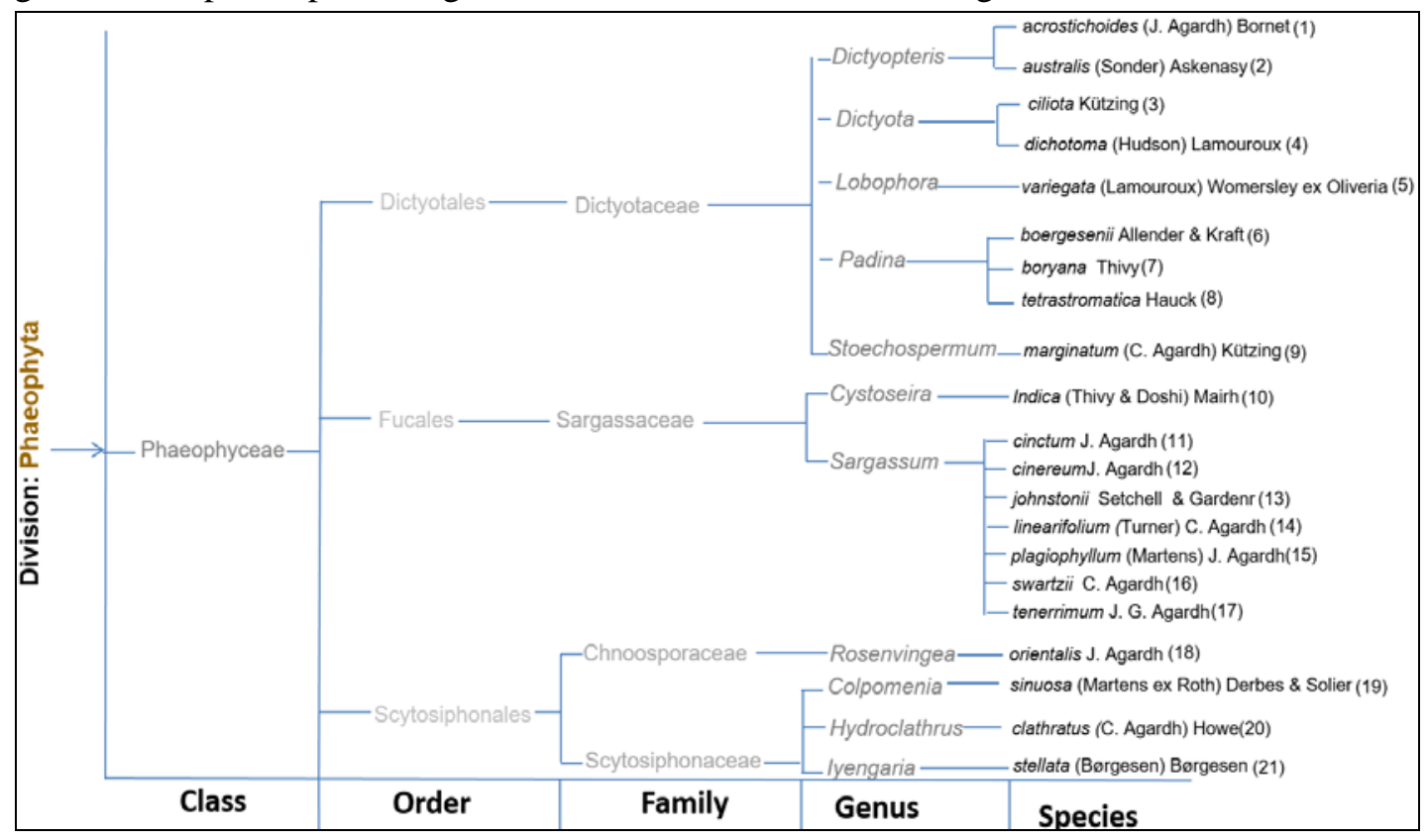

Figure 2: Cladogram of Phaeophyta species sampled from shore platform, Dwarka.

\section{RESULTS AND DISCUSSION}

The shore platform of Dwarka was further divided into three microzones in EastWest direction representing sectional cross-profiles. These micro-zones are: a) Cliff-base; b) Mixed zone; c) Subtidal zone. These zones are based on the general geomorphological and topographical characteristics of the shore platform, level of tidal inundation and dominance of seaweeds. Seaweeds' distribution was tagged with shore platform's zonal morphology as part of this study. The cliff base zone has many rock shore pools as compared to other zones. Mixed zone also has rock pools, but in less frequency. The subtidal zone is almost submerged in water; exposed only during spring tide.

Seaweeds on the shore platform were studied based on systematic random sampling for two years (April, 2013 - March, 2015). 21 taxa of Phaeophyta (Tab. 1) were identified from this site through intensive fieldwork based on Line Intercept Transect (LIT) and Quadrate based sampling methods. Phaeophyta belongs to three orders, four families, 11 genus and 21 species as shown in the cladogram. Each species was studied with respect to their occurrences and frequencies observed through quadrate survey within the three zones.

A detailed analysis of the field data shows that the 21 taxa of Phaeophyta can be classified into five major groups as per their zonal preferences on the shore platform. These five groups include: I) indicator species of subtidal zone; II) common species of cliff base and mixed zone; III) common species of mixed zone and subtidal zone; IV) chance factor species; V) ubiquitous found species. 


\section{Indicator species of subtidal zone}

In this group, only one species Dictyota dichotoma (Hudson) Lamouroux (Fig. 3A) was found. This species occurred in the subtidal zone of all the sections of the shore platform and was absent in either the mixed zone or the cliff-base region. Therefore, it is tagged as an indicator species of the subtidal zone.

\section{Common species of cliff base and mixed zone}

Three species: Padina boergesenii Allender and Kraft (Fig. 3B), Cystoseira indica (Thivy and Doshi) Mairh (Fig. 3C) and Sargassum swartzii Agardh C. were found. These were recorded in the cliff base and mixed zones of the northern, central and southern sections. The first one belongs to the Dictyotaceae while the last two to Sargassaceae.

\section{Common species of mixed zone and subtidal zone}

Lobophora variegata (Lamouroux) Womersley ex Oliveria (Fig. 3D), Padina boryana Thivy, Stoechospermum marginatum (Agardh C.) Kützing (Fig. 3E) and Hydroclathrus clathratus (Agardh C.) Howe (Fig. 3F). H. clathratus and L. variegata were found in mixed and subtidal zones of central and southern sections. $P$. boryana and $S$. marginatum in mixed and subtidal zones of northern, central and southern sections. The first three species belong to Dictyotaceae while the fourth one to Scytosiphonaceae.

\section{Chance Factor Species}

The fourth group represents the chance factor species as they were encountered only for once during the field surveys. Three species are included in this group: Dictyopteris acrostichoides (Agardh J.) Bornet (Fig. 3G), Dictyopteris australis (Sonder) Askenasy (Fig. $3 \mathrm{H}$ ) and Rosenvingea orientalis Agardh J. D. acrostichoides was recorded once only in the mixed zone of southern section in the month of November while D. australis was also found in the mixed zone of the northern section in April. $R$. orientalis was recorded in the cliff base of the central section during October. The first two species belong to Dictyotaceae family while the last one belongs to Chnoosporaceae family.

\section{Ubiquitous found species}

Ten out of 21 species were found ubiquitously present on the shore platform. These species include Dictyota ciliolata Kützing, Padina tetrastromatica Hauck (Fig. 4A), Sargassum cinctum Agardh J. (Fig. 4B), Sargassum cinereum Agardh J. (Fig. 4C), Sargassum johnstonii Setchell and Gardner (Fig. 4D), Sargassum linearifolium (Turner) Agardh C. (Fig. 4E), Sargassum plagiophyllum (Martens) Agardh J. and Sargassum tenerrimum Agardh J. G. (Fig. 4F), Colpomenia sinuosa (Martens ex Roth) Derbes and Solier (Fig. 4G), Iyengaria stellata (Børgesen) Børgesen (Fig. 4H). These species do not show microhabitat preference. These were found in all three zones of all three sections. The first two species belong to Dictyotaceae family and the last two belongs to Scytosiphonaceae. The remaining six species belong to Sargassaceae family and Sargassum genus.

Globally, very few reports are available on Phaeophyta and their habitat preferences. Monterio and Engelen (2012) have studied habitat related difference in recruitment and early survival of the invasive seaweed Sargassum muticum (Yendo) Fensholt in relation to the lunar phase and meso-grazing between mid-intertidal and lowintertidal pools in site name northern Portugal. In this study, in-situ experiments were performed to determine recruitment and to test the effect of mid-intertidal and low-intertidal pools, grazing and lunar phases (full, new and each quarter moon) on recruit survival reproduction seasons in two consecutive years. They have found recruitment and survival of Sargassum muticum higher in the mid-intertidal pools than in low-intertidal environments in both the study periods. 
Table 1: Spatial variation of Phaeophyta species observed at shore platform, Dwarka (P - Presence, A - Absence).

\begin{tabular}{|c|c|c|c|c|}
\hline \multicolumn{5}{|c|}{ Northern Section } \\
\hline $\begin{array}{l}\text { Sr. } \\
\text { no. }\end{array}$ & Name of species & $\begin{array}{l}\text { Cliff } \\
\text { base }\end{array}$ & $\begin{array}{c}\text { Mixed } \\
\text { zone }\end{array}$ & $\begin{array}{l}\text { Subtidal } \\
\text { zone }\end{array}$ \\
\hline 1. & Dictyopteris acrostichoides (J. Agardh) Bornet & A & A & A \\
\hline 2. & Dictyopteris australis (Sonder) Askenasy & A & $\mathrm{P}$ & A \\
\hline 3. & Dictyota ciliolata Kützing & $\mathrm{P}$ & A & A \\
\hline 4. & Dictyota dichotoma (Hudson) Lamouroux & A & A & $\mathrm{P}$ \\
\hline 5. & Lobophora variegata (Lamouroux) Womersley ex Oliveria & A & A & A \\
\hline 6. & Padina boergesenii Allender and Kraft (Juvenile) & A & $\mathrm{P}$ & A \\
\hline 7. & Padina boryana Thivy & A & $\mathrm{P}$ & A \\
\hline 8. & Padina tetrastromatica Hauck & $\mathrm{P}$ & $\mathrm{P}$ & $\mathrm{P}$ \\
\hline 9. & Stoechospermum marginatum (Agardh C.) Kützing & A & $\mathrm{P}$ & $\mathrm{P}$ \\
\hline 10. & Cystoseira indica (Thivy and Doshi) Mairh & $\mathrm{P}$ & $\mathrm{P}$ & A \\
\hline 11. & Sargassum cinctum Agardh J. & A & A & A \\
\hline 12. & Sargassum cinereum Agardh J. & $\mathrm{P}$ & $\mathrm{P}$ & $\mathrm{P}$ \\
\hline 13. & Sargassum johnstonii Setchell and Gardner & A & $\mathrm{P}$ & A \\
\hline 14. & Sargassum linearifolium (Turner) Agardh C. & $\mathrm{P}$ & A & $\mathrm{P}$ \\
\hline 15. & Sargassum plagiophyllum (Martens) Agardh J. & A & $\mathrm{P}$ & \\
\hline 16. & Sargassum swartzii Agardh C. & A & A & A \\
\hline 17. & Sargassum tenerrimum Agardh J. G. & A & A & A \\
\hline 18. & Rosenvingea orientalis Agardh J. & A & A & A \\
\hline 19. & Colpomenia sinuosa (Martens ex Roth) Derbes and Solier & $\mathrm{P}$ & $\mathrm{P}$ & $\mathrm{P}$ \\
\hline 20. & Hydroclathrus clathratus (Agardh C.) Howe & A & A & A \\
\hline 21. & Iyengaria stellata (Børgesen) Børgesen & A & $\mathrm{P}$ & A \\
\hline \multicolumn{5}{|c|}{ Central Section } \\
\hline 1. & Dictyopteris acrostichoides (Agardh J.) Bornet & A & A & A \\
\hline 2. & Dictyopteris australis (Sonder) Askenasy & A & A & A \\
\hline 3. & Dictyota ciliolata Kützing & A & $\mathrm{P}$ & A \\
\hline 4. & Dictyota dichotoma (Hudson) Lamouroux & A & A & $\mathrm{P}$ \\
\hline 5. & Lobophora variegata (Lamouroux) Womersley ex Oliveria & A & $\mathrm{P}$ & $\mathrm{P}$ \\
\hline 6. & Padina boergesenii Allender and Kraft (Juvenile) & A & A & A \\
\hline 7. & Padina boryana Thivy & A & $\mathrm{P}$ & A \\
\hline 8. & Padina tetrastromatica Hauck & A & $\mathrm{P}$ & A \\
\hline 9. & Stoechospermum marginatum (Agardh C.) Kützing & A & $\mathrm{P}$ & $\mathrm{P}$ \\
\hline 10. & Cystoseira indica (Thivy and Doshi) Mairh & $\mathrm{P}$ & $\mathrm{P}$ & A \\
\hline 11. & Sargassum cinctum Agardh J. & A & $\mathrm{P}$ & $\mathrm{P}$ \\
\hline 12. & Sargassum cinereum Agardh J. & A & $\mathrm{P}$ & $\mathrm{P}$ \\
\hline 13. & Sargassum johnstonii Setchell and Gardner & $\mathrm{P}$ & $\mathrm{P}$ & $\mathrm{P}$ \\
\hline
\end{tabular}


Table 1 (continued): Spatial variation of Phaeophyta species observed at shore platform, Dwarka (P - Presence, A - Absence).

\begin{tabular}{|c|c|c|c|c|}
\hline $\begin{array}{l}\text { Sr. } \\
\text { no. }\end{array}$ & Name of species & $\begin{array}{l}\text { Cliff } \\
\text { base }\end{array}$ & $\begin{array}{l}\text { Mixed } \\
\text { zone }\end{array}$ & $\begin{array}{c}\text { Subtidal } \\
\text { zone }\end{array}$ \\
\hline 14. & Sargassum linearifolium (Turner) Agardh C. & $\mathrm{P}$ & A & A \\
\hline 15. & Sargassum plagiophyllum (Martens) Agardh J. & A & $\mathrm{P}$ & A \\
\hline 16. & Sargassum swartzii Agardh C. & $\mathrm{P}$ & A & A \\
\hline 17. & Sargassum tenerrimum Agardh J. G. & A & $\mathrm{P}$ & A \\
\hline 18. & Rosenvingea orientalis Agardh J. & $\mathrm{P}$ & A & A \\
\hline 19. & Colpomenia sinuosa (Martens ex Roth) Derbes and Solier & A & $\mathrm{P}$ & $\mathrm{P}$ \\
\hline 20. & Hydroclathrus clathratus (Agardh C.) Howe & A & A & $\mathrm{P}$ \\
\hline 21. & Iyengaria stellata (Børgesen) Børgesen & $\mathrm{P}$ & $\mathrm{P}$ & A \\
\hline \multicolumn{5}{|c|}{ Southern Section } \\
\hline 1. & Dictyopteris acrostichoides (Agardh J.) Bornet & A & $\mathrm{P}$ & A \\
\hline 2. & Dictyopteris australis (Sonder) Askenasy & A & A & A \\
\hline 3. & Dictyota ciliolata Kützing & $\mathrm{P}$ & A & $\mathrm{P}$ \\
\hline 4. & Dictyota dichotoma (Hudson) Lamouroux & A & A & $\mathrm{P}$ \\
\hline 5. & Lobophora variegata (Lamouroux) Womersley ex Oliveria & A & $\mathrm{P}$ & $\mathrm{P}$ \\
\hline 6. & Padina boergesenii Allender and Kraft (Juvenile) & $\mathrm{P}$ & $\mathrm{P}$ & A \\
\hline 7. & Padina boryana Thivy & A & $\mathrm{P}$ & $\mathrm{P}$ \\
\hline 8. & Padina tetrastromatica Hauck & $\mathrm{P}$ & $\mathrm{P}$ & A \\
\hline 9. & Stoechospermum marginatum (Agardh C.) Kützing & A & $\mathrm{P}$ & A \\
\hline 10. & Cystoseira indica (Thivy and Doshi) Mairh & $\mathrm{P}$ & $\mathrm{P}$ & A \\
\hline 11. & Sargassum cinctum Agardh J. & $\mathrm{P}$ & $\mathrm{P}$ & $\mathrm{P}$ \\
\hline 12. & Sargassum cinereum Agardh J. & A & $\mathrm{P}$ & $\mathrm{P}$ \\
\hline 13. & Sargassum johnstonii Setchell and Gardner & A & $\mathrm{P}$ & A \\
\hline 14. & Sargassum linearifolium (Turner) Agardh C. & $\mathrm{P}$ & $\mathrm{P}$ & $\mathrm{P}$ \\
\hline 15. & Sargassum plagiophyllum (Martens) Agardh J. & $\mathrm{P}$ & $\mathrm{P}$ & A \\
\hline 16. & Sargassum swartzii Agardh C. & $\mathrm{P}$ & $\mathrm{P}$ & A \\
\hline 17. & Sargassum tenerrimum Agardh J. G. & $\mathrm{P}$ & $\mathrm{P}$ & $\mathrm{P}$ \\
\hline 18. & Rosenvingea orientalis Agardh J. & A & A & A \\
\hline 19. & Colpomenia sinuosa (Martens ex Roth) Derbes and Solier & A & $\mathrm{P}$ & $\mathrm{P}$ \\
\hline 20. & Hydroclathrus clathratus (Agardh C.) Howe & A & $\mathrm{P}$ & $\mathrm{P}$ \\
\hline 21. & Iyengaria stellata (Børgesen) Børgesen & $\mathrm{P}$ & $\mathrm{P}$ & $\mathrm{P}$ \\
\hline
\end{tabular}


Santelices and Ojeda (1984) studied recruitment, growth and survival of the lowintertidal, shallow-subtidal Lessonia nigrescens Bory de-Saint-Vincent at four tidal levels in rocky habitats in Chile. They have found the effect of the abiotic environment, small grazers and mid-littoral algae on the survival of the juvenile of L. nigrescens recruited in the upper part of it vertical range. Disturbance effects of adult plants, grazing effects of large-sized subtidal herbivores on juvenile recruitment and effects of interspecific interference on the survival of newly settled juveniles were also evaluated. The studies focus on recruitment, growth and survival factors of the phaeophyceae species in rock shore platform, India.

Many of phycologists and researchers have studied the seaweeds of Gujarat and India. Iyengar (1927) was the first phycologist to report marine flora of the Indian coast.

Many researchers studied the seasonal variation (Jayasankar and Paliwal, 2002; Dhargalkar et al., 2001; Dhargalkar and Deshmukhe, 1996; Kesava Rao and Singbal, 1995), frequency and biomass (Satheesh and Wesley, 2012), growth cycle (Kotiya et al., 2011), etc. of seaweeds of India, but so far no one has studied microhabitat preference of Phaeophyta in such species level detail from the India coast.

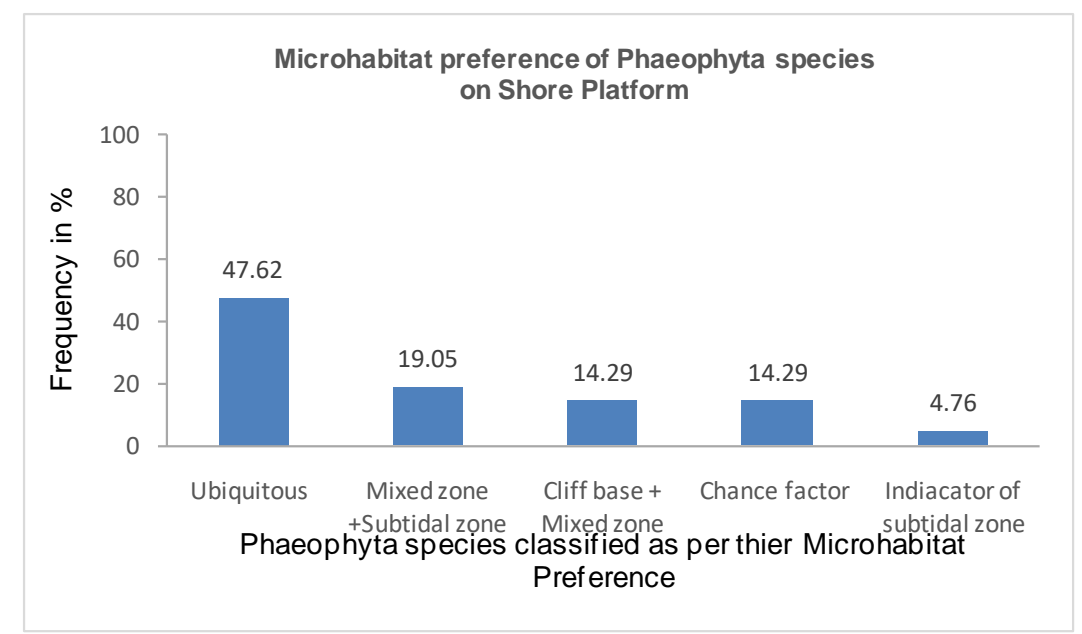

Figure 5: Microhabitat Preference of Phaeophyta on Shore Platform, Dwarka, Guajrat.

Were found 21 Phaeophyta species of four families i.e. Dictyotaceae, Sargassaceae, Chnoosporaceae and Scytosiphonaceae. Eight species have been found in Sargassaceae family, eight in Dictyotaceae, one in Chnoosporaceae and three in Scytosiphonaceae. From eight species of Sargassaceae family, six are showing ubiquitous distribution in the shore platform, while the other two show cliff base and mixed zone distribution. From eight species of Dictyotaceae family two species are showing ubiquitous distribution, two show mixed zone and subtidal zone, one species shows cliff base and mixed zone, two species are chance factor and one species showing subtidal zone distribution in the shore platform. It shows that Sargassaceae dominates on all the zones and can colonize intertidal as well the subtidal zones, while Dictyotaceae mostly prefers subtidal and parts of intertidal zone (i.e. in the mixed zone) and does not occur in the cliff base part which is the most dry part of study area with respect to tidal inundation. $47.62 \%$ is ubiquitous, $14.29 \%$ cliff base and mixed zone, $19.05 \%$ mixed zone and subtidal zone, $14.29 \%$ chance factor and $4.76 \%$ indicator species of subtidal zone in the shore platform (Fig. 5). 


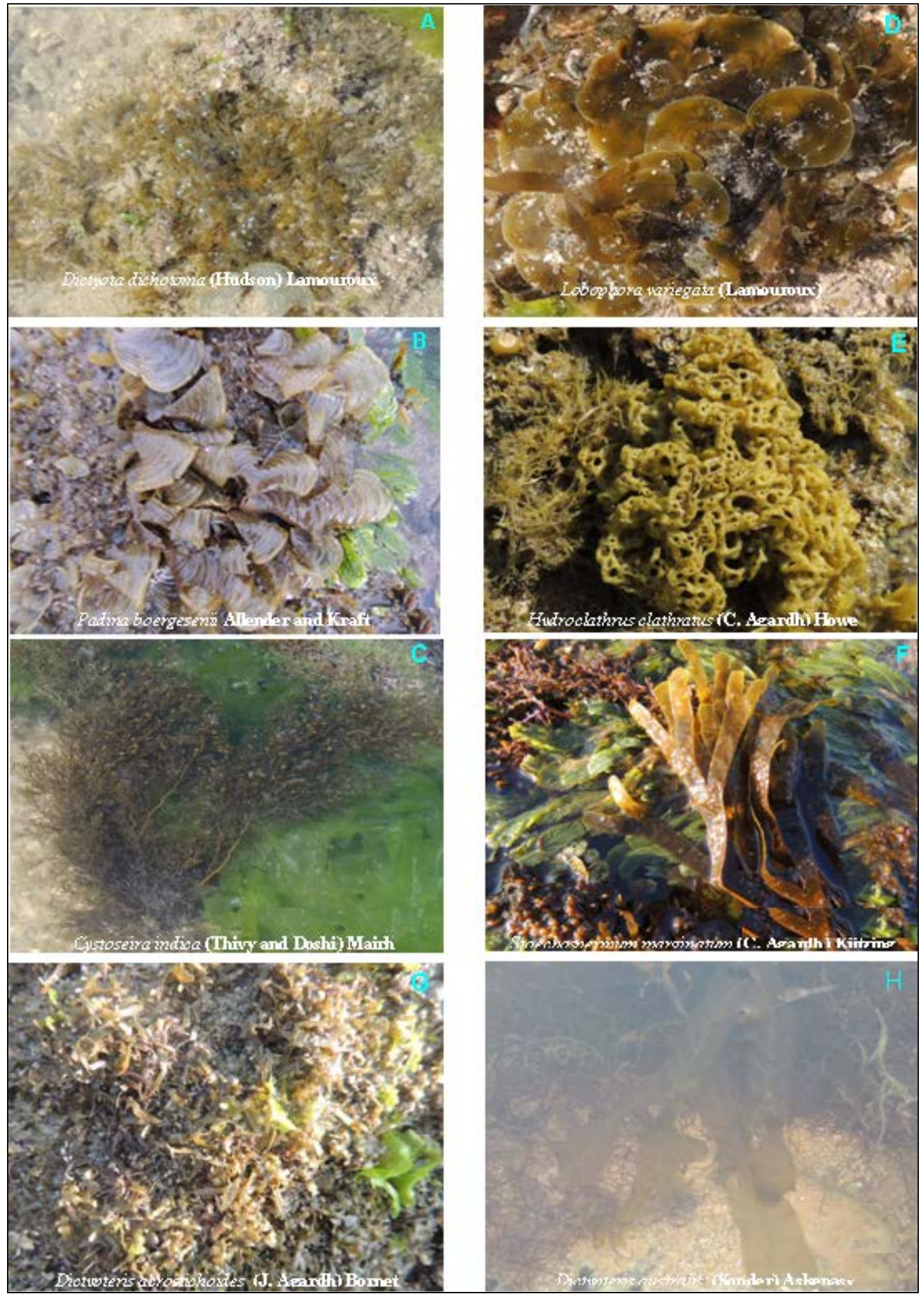

Figure 3: indicator species on shore Platform: A) ind. of subtidal Zone; B-C) ind. of cliff base and mixed zone; D-F) ind. of mixed and subtidal zones; G-H) chance factor. 

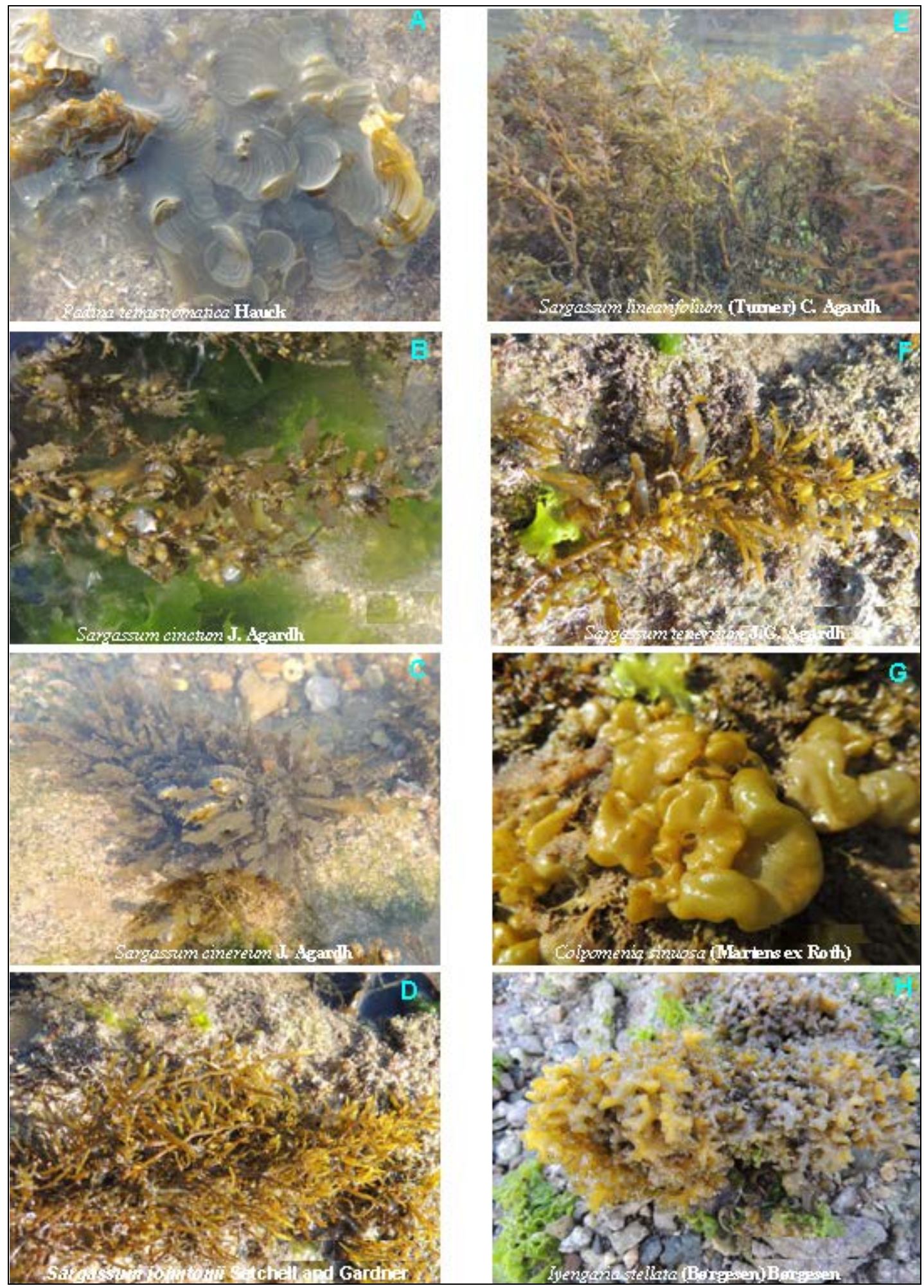

Figure 4: A-H) Photograph of ubiquitous species on shore platform. 


\section{CONCLUSIONS}

This study reports microhabitat preferences of Phaeophyta from the shore platform of Dwarka in an additional dimension for future field-based macroalgae monitoring. 47.62\% of phaeophyta were found to have ubiquitous distribution. Sargassaceae members are most ubiquitous on shore platform. Five out of eight species of Sargassaceae found ubiquitous. Dictyotaceae members still show microhabitat preference on the shore platform. It was mostly found in mixed zone and subtidal zone. Dictyota dichotoma (Hudson) Lamouroux is a species of Pheaophyta in subtidal zone of shore platform, Dwarka. This work can serve as a baseline data for designing field sampling strategies exclusively for monitoring Phaeophyta and related biodiversity in the shore platform of Dwarka. Microhabitat preference of the Pheaophyta species thus can become an additional dimension for future field-based macroalgae inventory and monitoring. The methodology adopted can be applied for other groups of seaweeds or for other shore platforms with case specific refinement.

\section{REFERENCES}

1. Chakraborty S. and Bhattacharya T., 2012 - Nutrient composition of marine benthic algae found in the Gulf of Kutch coastline, India, Journal of algal Biomass Utilization, 3, 1, 32-38.

2. Dhargalkar V. K. and Deshmukhe G. V., 1996 - Subtidal marine algae of the Dwarka coast (Gujarat), Indian Journal of Marine Sciences, 25, 297-301.

3. Dhargalkar V. K. and Kavlekar D., 2004 - Seaweeds - a field manual, Verlecar X. N., Rathod V. and Kavlecar D. (eds), National Institute of Oceanography, Dona Paula, Goa, 42.

4. Dhargalkar V. K., Untawale A. G. and Jagtap T. G., 2001 - Marine macroalgal diversity along the Maharashtra coast, Indian Journal of Marine Sciences, 30, 18-24.

5. Gohil B. and Kundu R., 2012 - Diversity of the intertidal macrofauna at west coast of Gujarat, India, Life Sciences Leaflet, December 2012, 12, 135-145.

6. Iyengar M. O. P., 1927 - Krusadai Island flora, Bulletin of the Madras Government Museum, New Series, Natural History Section, 1, 185-188.

7. Jayasankar R. and Paliwal K., 2002 - Seasonal variation in the elemental composition of Gracilaria species of the Gulf of Mannar, Seaweed Resources Utilisation, 24, 1, 55-59.

8. Jha B., Reddy C. R. K., Thakur M. C. and Umamaheswara Rao M., 2009 - Seaweeds of India the diversity and distribution of seaweeds of Gujarat Coast, Springer, New York, 215.

9. Kesava Rao C. and Singbal S. Y. S., 1995 - Seasonal variations in halides in marine brown algae from porbandar and Okha coasts, Indian Journal of Marine Sciences, 24, 137-141.

10. Kotiya A. S., Gunalan B., Parmar H. V., Jailkumar M., Dave T., Solanki J. B. and Makwan N. P., 2011 - Growth comparison of the seaweed Kappaphycus alvarezii in nine different coastal areas of Gujarat coast, India, Advances in Applied Science Research, 2, 3, 99-106.

11. Monterio C. A. and Engelen A. H., 2012 - Habitat-related differences in recruitment and survival of early recruits of Sargassum muticum in Portugal, Hydrobiologia, 683, 287-296.

12. Sanghvi D., Ray Chaudhury N. and Jain B. K., 2014 - Spatial and temporal profiling of macroalgal groups on shore platform, International Journal of Marine Science, 66, 1-11.

13. Santelices B. and Ojeda F. P., 1984 - Recruitment, growth and survival of Lessonia nigrescens in exposed habitats of central Chile, Marine-Ecology-Progress Series, 19, 73-82.

14. Satheesh S. and Wesley S. G., 2012 - Diversity and distribution of seaweeds in the Kudankulam coastal waters, South-Eastern coast of India, Biodiversity Journal, 3, 1, 79-84.

15. Singh A. K., Ansari A., Kumar D. and Sarkar U., 2012 - Status, biodiversity and distribution of mangroves in India, International Day for Biological Diversity Marine Biodiversity, 57-67.

16. Subba Rao P. V. and Mantri V. A., 2006 - Indian seaweed resources and sustainable utilization: Scenario at the dawn of a new century, Current Science, 91, 2, 164-174.

17. Thahira B. A., 2011 - Nutrient composition, antioxidant activity and therapeutic uses of selected seaweeds, PhD Thesis, Avinashilingan Deemed University for Women, 2011.

18. Woodward S. H., 2003 - Coastal Biomes, in Woodward S. H. (ed.) Biomes of Earth: Terrestrial Aquatic and Human Dominated, Greenwood Press, 456. 